\title{
Employing Water Demand Management Option for the Improvement of Water Supply and Sanitation in Nigeria
}

\author{
Emma E. Ezenwaji1', Bede M. Eduputa ${ }^{2}$, Joseph E. Ogbuozobe ${ }^{1}$ \\ ${ }^{1}$ Department of Geography and Meteorology, Nnamdi Azikiwe University, Awka, Nigeria \\ ${ }^{2}$ Department of Environmental Management, Nnamdi Azikiwe University, Awka, Nigeria \\ Email: emmaezenwaji@gmail.com
}

Received 7 May 2015; accepted 26 June 2015; published 29 June 2015

Copyright (C) 2015 by authors and Scientific Research Publishing Inc.

This work is licensed under the Creative Commons Attribution International License (CC BY).

http://creativecommons.org/licenses/by/4.0/

(c) (i) Open Access

\begin{abstract}
The aim of this paper is to assess the importance of Water Demand Management (WDM) strategy to the improvement of water supply and sanitation in Nigeria. Persistent water supply shortages and poor sanitation have since remained important features of the Nigerian urban and rural communities. Most often governmental solution to these problems has been to develop and exploit the available water resources and the level of sanitation for the people. This predominant approach which is also known as augmentation method is supply driven with the primary purpose being how best to meet the perceived water and sanitation demand. One of the major disadvantages of this approach is the huge financial involvement associated with it. Conversely, quite recently water resource managers have begun to direct attention on how consumers can be motivated to regulate the amount and manner in which they use and dispose water to alleviate pressure on freshwater supplies. This new approach is known as water demand management. It is demand driven in that consumers determine their own water need. Employment of WDM by consumers especially in water scarce areas as was discussed in the paper will decrease the amount of water use, thereby limiting unnecessary financial expenditure in exploiting new sources to meet the ever increasing demand.
\end{abstract}

\section{Keywords}

Approach, Assess, Demand, Management, Sustainable

\section{Introduction}

Nigeria, like most developing countries especially in sub-Saharan Africa is facing serious water crises. All signs

How to cite this paper: Ezenwaji, E.E., Eduputa, B.M. and Ogbuozobe, J.E. (2015) Employing Water Demand Management Option for the Improvement of Water Supply and Sanitation in Nigeria. Journal of Water Resource and Protection, 7, 624635. http://dx.doi.org/10.4236/jwarp.2015.78051 
indeed show that it is getting worse and will continue to deteriorate if not checked by corrective action. The continuously intensifying scarcity of water resources according to [1] is a crucial problem. The primary reason for the water scarcity being experienced in Nigeria could be traced to growing disparity between the decreasing effective supply and increasing demand for water [2] [3]. The causes of this obvious imbalance between urban demand and water supply manifests in the continuous inability of supply quantities to meet demand. This could be traced to the population growth, higher living standards, increased irrigation, urbanization coupled with the impacts of climate change [4]. Water is, therefore, scarce in all its sectors including residential, industrial, commercial, public institutions, agricultural and a range of others. In Nigeria, apart from agricultural water requirements, residential water needs ranks highest in water demand among the sectors. In this paper, we shall as a result, focus attention on the residential water demand and sanitation. This is on the understanding that water consumers in this sector are most vulnerable to the negative impacts of water scarcity and poor sanitation. This is because people daily eat, wash, bath, drink and engage in other water consuming activities at home and the situation is in contrast with the happenings in other sectors where water consumption is not on daily basis because generally weekends especially Sundays are not included in their normal activities. That residential consumers easily contact water borne diseases such as typhoid, dysentery, cholera, and others is no longer in doubt. In addition, the residential water consumers produce wastewater in course of their water using activities from such areas as household bathrooms, toilets wash hand basins and kitchen sinks which are often not properly disposed and as a result create aesthetic nuisance and breeding ground for mosquitoes and other pests.

The traditional policy which has continued to dominate our action towards confronting water scarcity and poor sanitation depend on utilizing new water resources and constructing more sanitation facilities. The transfer of water from remote sources at times as far as $200 \mathrm{~km}$ away and the continued exploitation of new resources around us especially the construction of boreholes has since dominated this supply policy. However, the efficacy of such a supply-side measure is being questioned now since the use of water resources have increased extensively and are reaching an impasse because water supply is by its very nature finite.

Apart from the fast depletion of the finite water resources, the supply augmentation has the added disadvantage of being associated with huge financial costs. To avert this problem water providers and their financial supporters have devised a means of managing the finite resources through supply management which is a water conservation method usually adopted by water supplying authorities, where such authorities take decisions on water management without involving the water consumers. This means that the authorities employ such water supply efficiency measures that are entirely within its own means but outside knowledge of the consumers.

In Nigeria, the various State Water Authorities (SWAs) employ this measure to periodically identify and repair water pipelines, assess the water needs of consumers, design tariff structures, reconstruct some water infrastructure, reduce the unaccounted for water (ufw), sensitize and enlighten consumers on the need to adopt water wise measures, increase the regulatory intervention etc. Quite regrettably, the water supply management option has failed to solve the perennial urban water supply problem in Nigeria because most of the SWAs pay lip services to these important functions, some of them fingering lack of funds as the major problem for their poor operation.

To overcome this obvious lack of commitment by the SWAs to properly manage supply, there has appeared a new policy model that aims at maximizing the benefits of the utilization of water resources and sanitation facilities already in use in order to minimize or even eliminate the need for new water supplies and sanitation facilities [1]. This policy option defined as Water Demand Management is gradually becoming popular especially in developed societies and mainly consists of the following actions:

1) the minimization of losses in storage systems,

2) the reuse of water,

3) the containment of water use to avoid waste, and

4) the efficient use of water and sanitation resources [5].

It is in this realization that this paper attempts to explain the continued urban residential water and sanitation problems in Nigeria and seeks to suggest the urgent need to employ the Water Demand Management option for the improvement of these services.

\section{Area of Study}

Nigeria with a land area of about $924,000 \mathrm{sq} \cdot \mathrm{km}$ is a country of immense water supply potential. Annual rainfall 
figure according to [6] varies from over $3000 \mathrm{~mm}$ in the Niger Delta areas and coastal south to less than $750 \mathrm{~mm}$ in the extreme northern parts. Using Thornthwaite's water budgeting procedure, [7] computed the climatic water balance for Nigeria using data from 32 stations. The result shows that out of the average rainfall over the country of $1397 \mathrm{~mm}$, about $1067 \mathrm{~mm}$ of this are lost through evapotranspiration process leaving $330 \mathrm{~mm}$ for surface and sub-surface run-off. The runoff coefficient of the country as a result is, therefore, about $23.64 \%$. In terms of surface water resources, the country is well drained with a very reasonable network of rivers and streams (Figure 1).

Altogether, the surface water resources stock of the country is estimated at 267.3 billion cubic metres [8]. However, it has been observed that the Nigerian rivers are generally turbid because they carry a lot of sediment load in suspection particularly during the rainy season. Some river water in Nigeria is acidic and somehow hard, and heavily biologically and chemically polluted as a result of riparian and watershed activities. It is, therefore, necessary that water from this source should be fully analysed and treated before consumption. Furthermore, Nigeria is rich in ground water resources. Quite often its quality and quantity depends on geology, climate and the underlying rocks. According to [7] boreholes sited in basement complex rocks do not yield as much water as those of sedimentary rocks. For example, yield of wells and boreholes in some locations in the cretaceous sedimentary rocks yield up to 22,730 litres/hr lending support to the findings by [8] that the ground water potential of Nigeria is about 51.9 billion cubic metres.

From the foregoing, it could be seen that Nigeria is well endowed with water resources. The issue then is not that of availability, but that of proper management. For instance, the total average annual surface run-off over the country computed using appropriate water budgeting method is about $330 \mathrm{~mm}$ as we had earlier noted and this translates to 835,654 million litres a day. The current residential water needs of the country computed with trend based method shows that with a population of about 160 million (projected from 2006 figure) and based

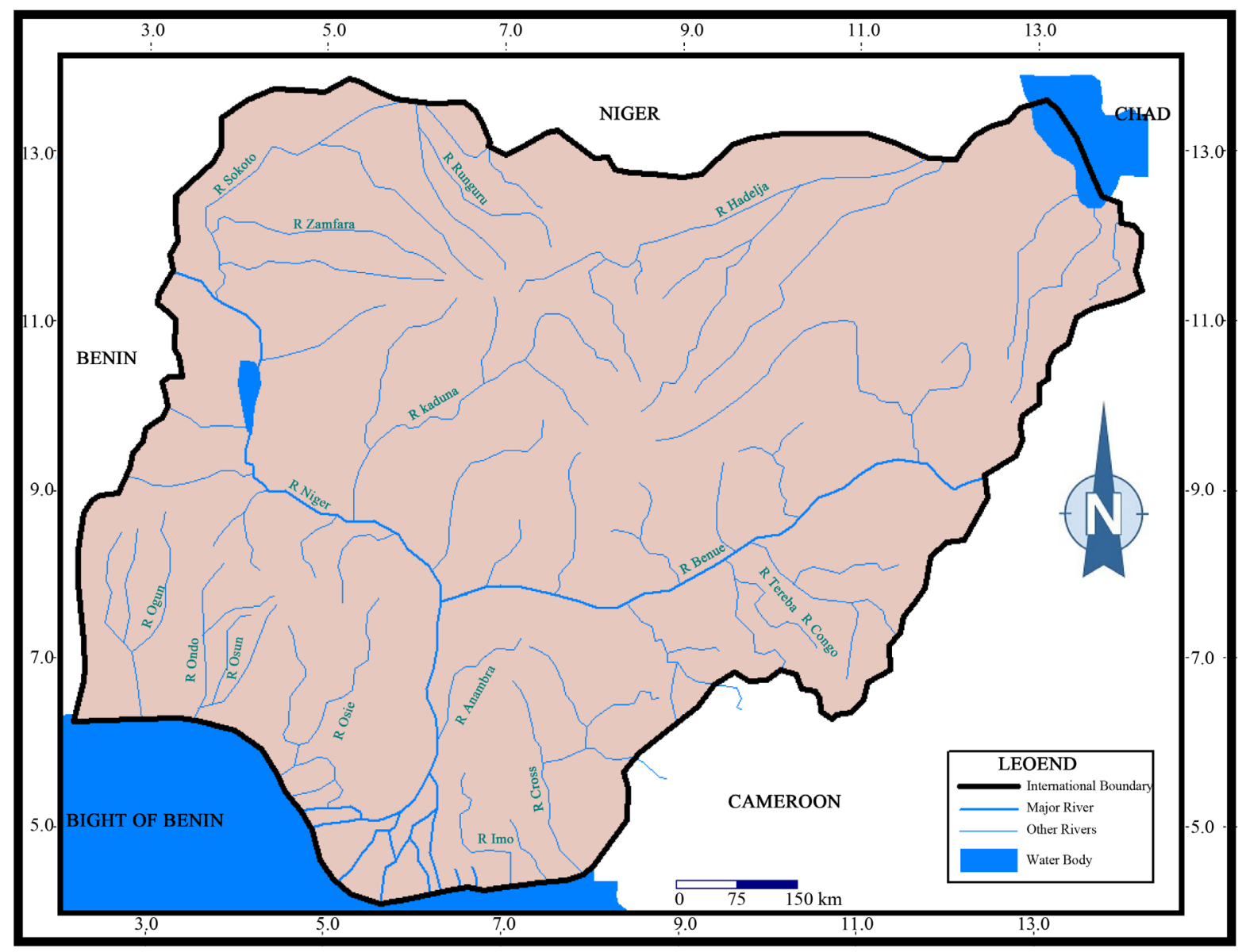

Figure 1. Nigeria’s river systems. 
on per-capita daily water use of 120 litres (Federal Government recommended level) is then 19,200 million litres/day. This represents $2.22 \%$ of the surface water potential of the country of 835,654 million litres/day which includes the underground water resources that is not as exploited as the surface water source. The provision of inadequate toile facilities in Nigeria and the fact that even when there is a flush toilet water to flush after use has increasingly become a problem. Graphs showing cases of water borne diseases associated with lack of potable water supply such as cholera, typhoid fever and dysentery indicate that in 14 selected states studied by the National Bureau of Statistics the situation is to say the least, worrisome.

\section{Methodology}

Data were collected from secondary source primarily the National Bureau of Statistics (NBS), Nigeria published in 2010. Data which were collected are on cases of water borne diseases in the 36 States of Nigeria and 6 geopolitical zones on the type of toilet mostly used by residents, main source of water supply, quality of water supply, etc. simple graphs such as bar and line charts were utilized in the analysis of data with the purpose of establishing patterns and relationships of identifying water related problems. Furthermore, oral interviews were conducted to verify some areas with doubtful figures in the public data.

\section{Results}

Figure 2 are graphs showing cases of water borne diseases such as cholera, typhoid fever, in the following selected state where data were available. The States are; Akwa-Ibom, Bauchi, Borno, Cross River, Edo, Ekiti, Gombe, Kwara, Ondo, Osun, Oyo, River and Taraba.

From Figure 2, it could be seen that Taraba ranks highest followed by Borno and Gombe States. Conversely the situation in such States as AkwaIbom, Ekiti and Edo are commendable.

Figure 3 indicates the position of some States regarding the use of different types of toilet ranging from very modern ones to the most obsolete. Types of toilets studied regarding their use are water closet (WC), pit latrine, bucket system, toilet facility in another dwelling, public toilet and nearby bush. Among them, pit toilet is the most widely used. The figure shows that Kaduna State has the highest patronage of pit latrine, but generally its usage is highest in all the selected States. The use of pit latrine is followed by that of nearby bush. These are indications of poor sanitation which expectedly gives rise to the prevalence of water borne diseases which we saw in Figure 2.

Again the cases of malaria outbreak in the States of the federation including Abuja shows that Imo State tops the table in 2007 with over 600,000 cases, Kastina in 2006 and 2005 had over 380,000 and 270,000 cases respectively, Osun with almost 400,000 and 300,000 cases in 2004 and in 2003, Kano with about 250,000 cases.

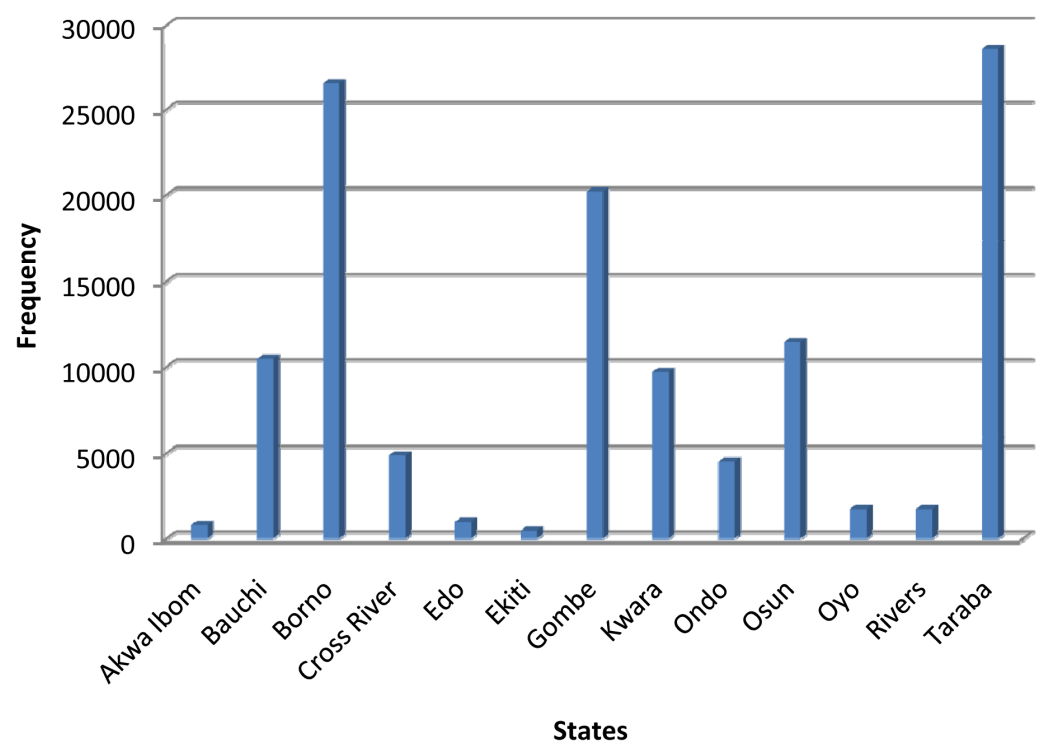

Water borne diseases occurrence

Figure 2. Bar chart of cases of water borne diseases in Nigeria (2008). 


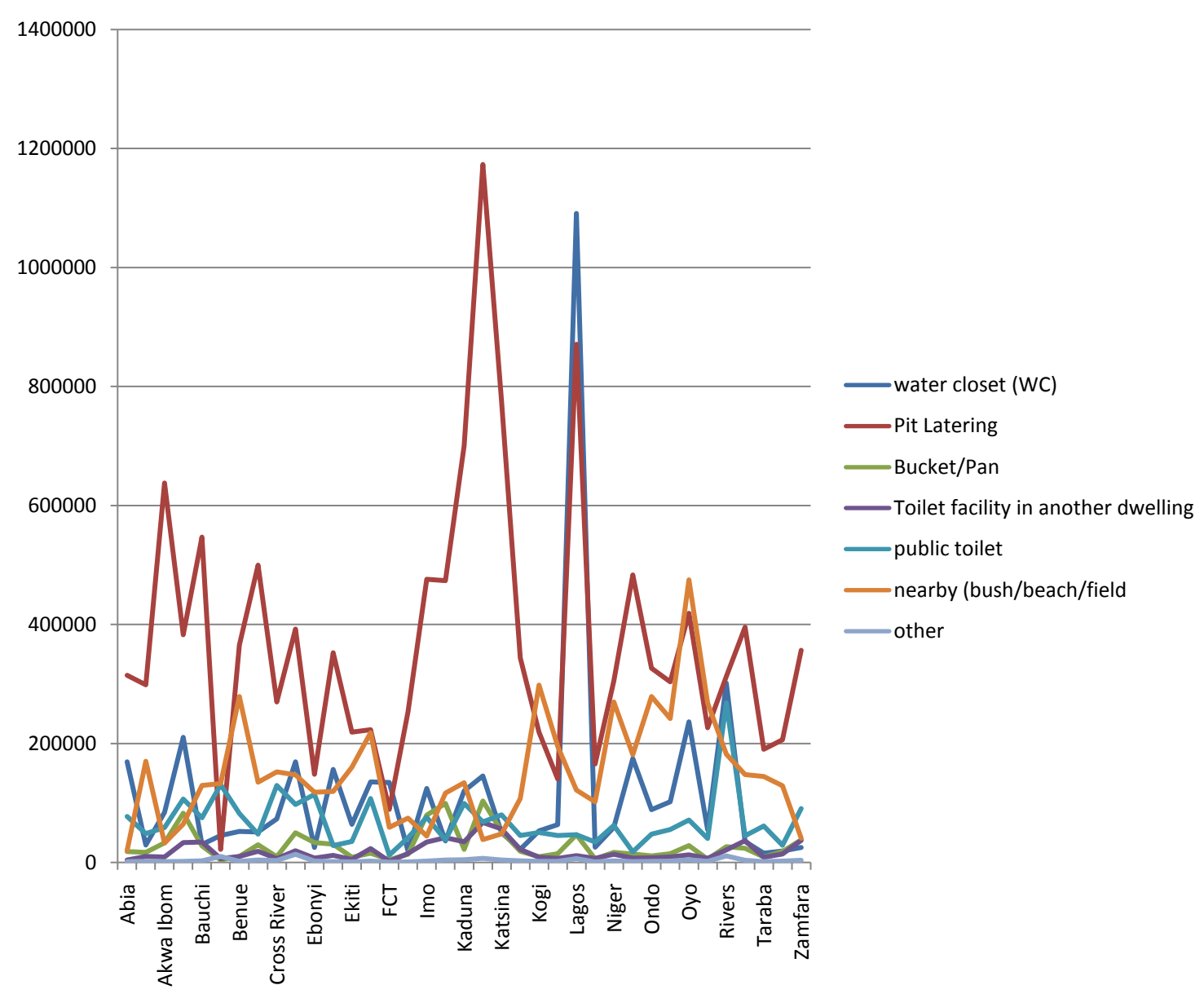

Figure 3. Line chart of type of toilet used in States in Nigeria.

The liquid wastes and other stagnant pools of water that are seen in many locations in our urban areas are ready breeding grounds for mosquitoes. Figure 4 shows the regional distribution of households by main source of water supply in Nigeria for domestic purpose.

It is seen in the figure that the North East zone ranks highest in the patronage of unprotected wells, followed by North West zone, South East and North Central tie as the highest in the reliance to rivers, lakes or ponds as sources of water. Southwest ranks highest in the use of treated pipe borne source. Generally all the zones are poor in harvesting rainwater for domestic water uses. The situation for individual States that make up each of the regions are shown in Figures 5(a)-(f).

In North East region, the use of pipe borne water is generally low while that of the unprotected wells are patronised heavily by all States in the region. In the Northwest patronage of treated pipe borne source is very poor. All the States in this region patronize unprotected wells with Zamfara State having a slightly higher figure than Sokoto. In North Central region, treated pipe borne water is patronized by all States with FCT having the highest. All the States in this zone have a high patronage of rivers, lakes or ponds with Benue ranking highest. However, in the use of water vendors, FCT stands out, in South East region, boreholes and hand pumps are well patronized with Abia ranking highest. All the States in this region patronize rivers, lakes and ponds. In the South West region, boreholes and hand pumps are equally heavily patronized with Lagos ranking highest. Finally, in the South-South region, boreholes and hand pumps receive the highest patronage followed by rivers, lakes and ponds with Bayelsa ranking highest in the use of rivers.

\section{Discussion}

The high level of water scarcity and high affliction of consumers with water borne disease have provoked the 


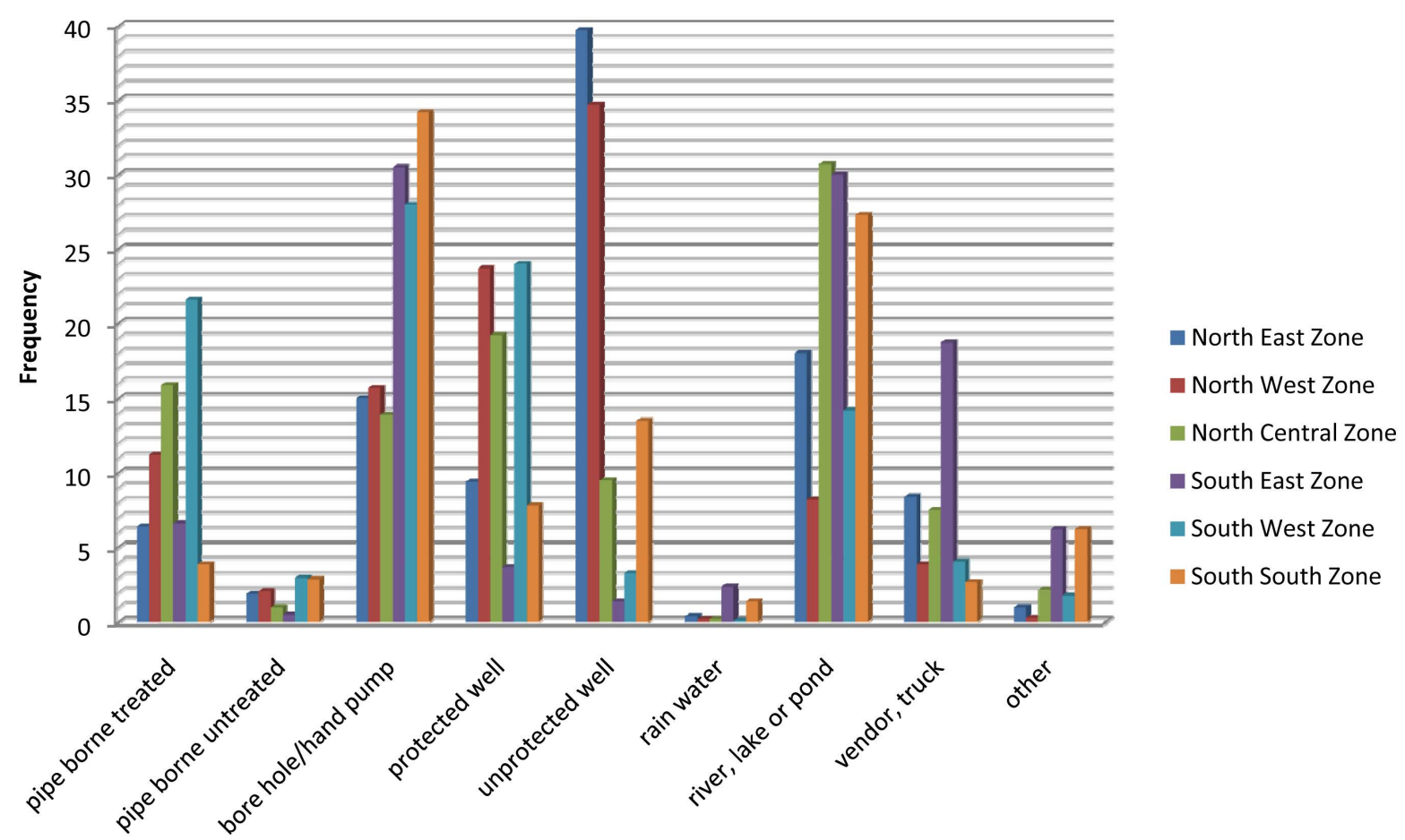

Source of Drinking Water

Figure 4. Sources of drinking water in the six Geopolitical Zones of Nigeria.

promotion of management strategy that can reasonably maintain the balance between water supply and demand balance. Water Demand Management (WDM) is aimed at achieving development by stressing that every drop of water must be utilized effectively. It emphasises reliance on socio-economic techniques to achieve the desired objectives. The focus of WDM strategy is more on consumers than on the supply of water from additional water sources.

WDM, therefore, strives to achieve water use efficiency in order to ensure sustainable and affordable water services [9]. The major reasons for WDM according to [10] include:

1) There is a limited environmental capacity of water resources system.

2) There is an ever increasing use of water, whereas the resources are limited such that with increased utilization, supply is diminishing.

3) There are increasing cost of developing new water sources especially as the easily accessible and cheap sources have already been develop. Countries are, therefore, experiencing limited investments due to financial constraints.

4) Water shortages are already occurring worldwide and the existing water development projects cannot be altered to meet the challenges facing many countries. Also [2] added that

5) WDM is usually employed to avert water crisis.

6) It is usually used by Water Corporations to buy time, delaying the need for large scale capital investment for the expansion of water supply. This is particularly of interest when capital for such development is a soft loan or credit from a Development Bank of a bilateral source. In most cases, the savings achieved by delaying an investment can provide financial resources that would more than cover the costs of implementing a comprehensive water demand programme.

The slow progress being made by WDM in the residential water and sanitation is as a result of a range of reasons, some of which are discussed here.

\subsection{Lack of Political Will}

One of the problems of WDM in solving the urban and rural residential water demand is lack of political will by 


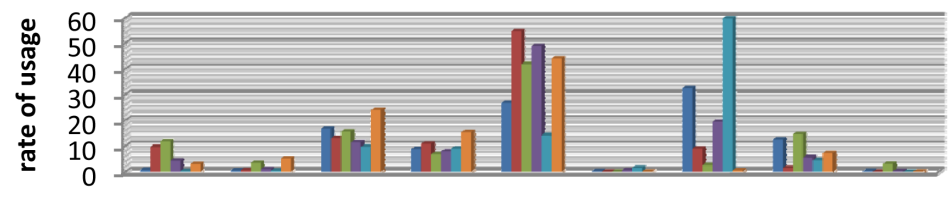

- Adamawa

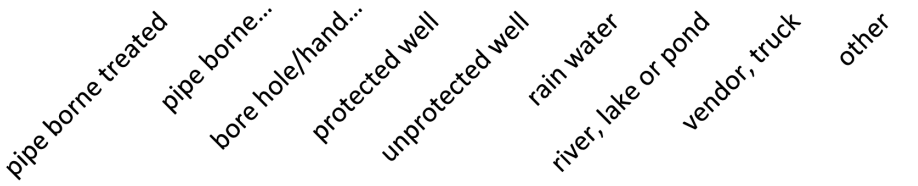

- Bauchi

Borno

Gombe

- Taraba

Yobe

Sources of water

(a)

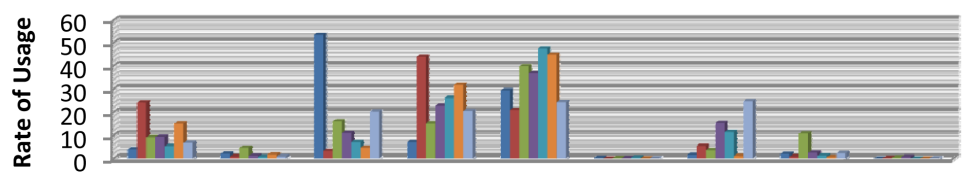

- Jigawa

Kaduna

- Kano

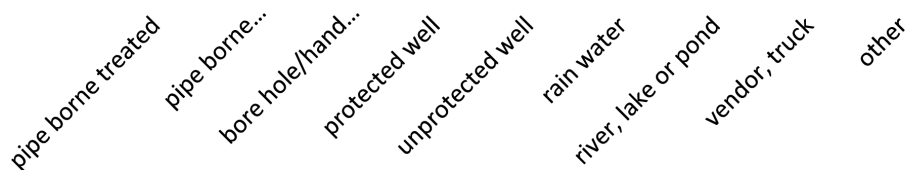

- Katsina

Kebbi

- Sokoto

Zamfara

(b)
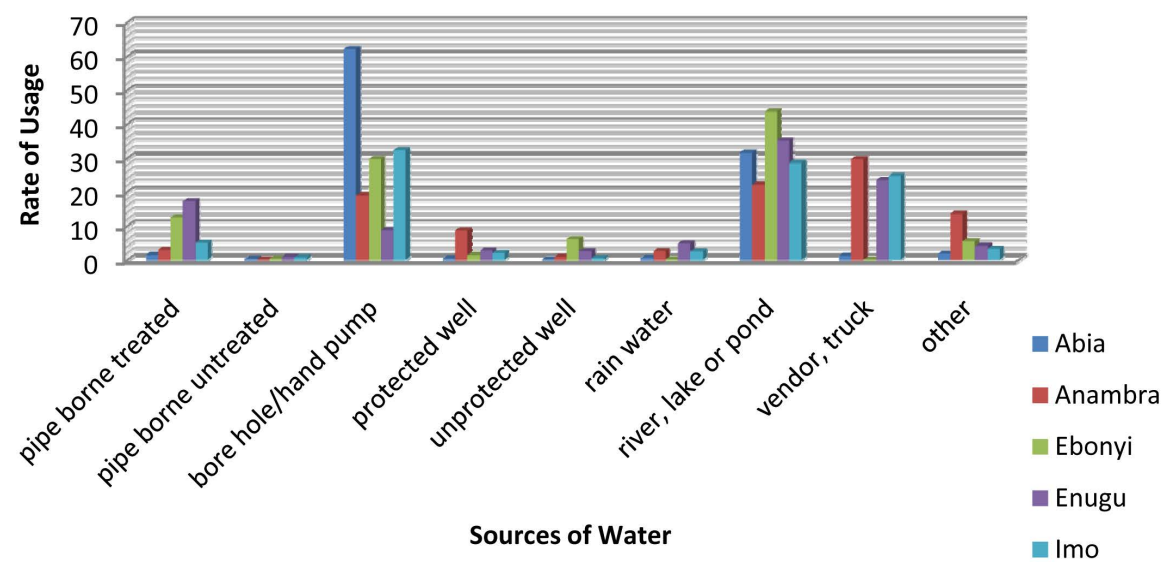

(c)

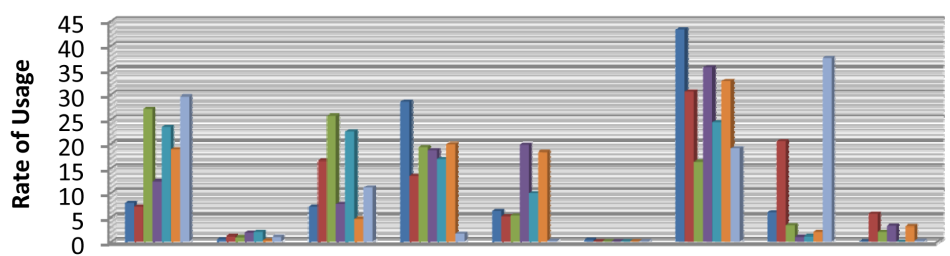

- Benue

- Kogi

- Kwara

nasarawa

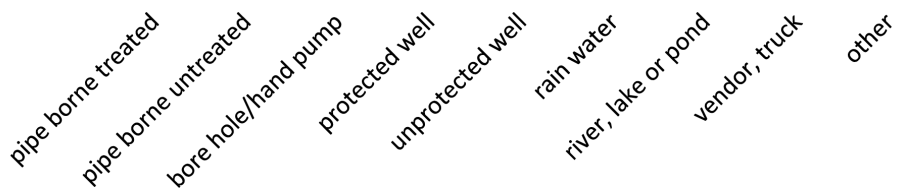

Niger

- Plateau

FCT

Sources of Water

(d) 


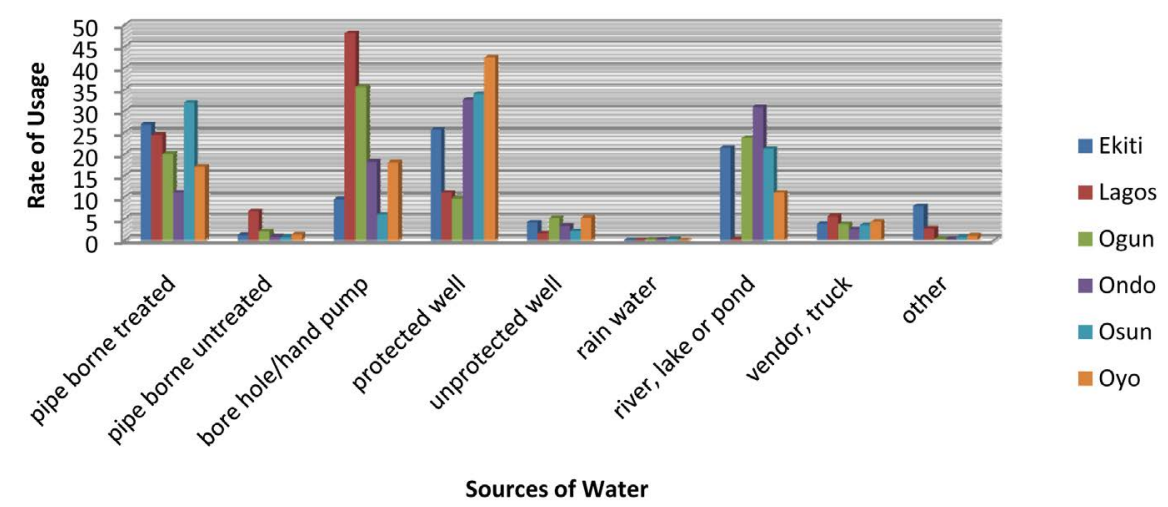

(e)

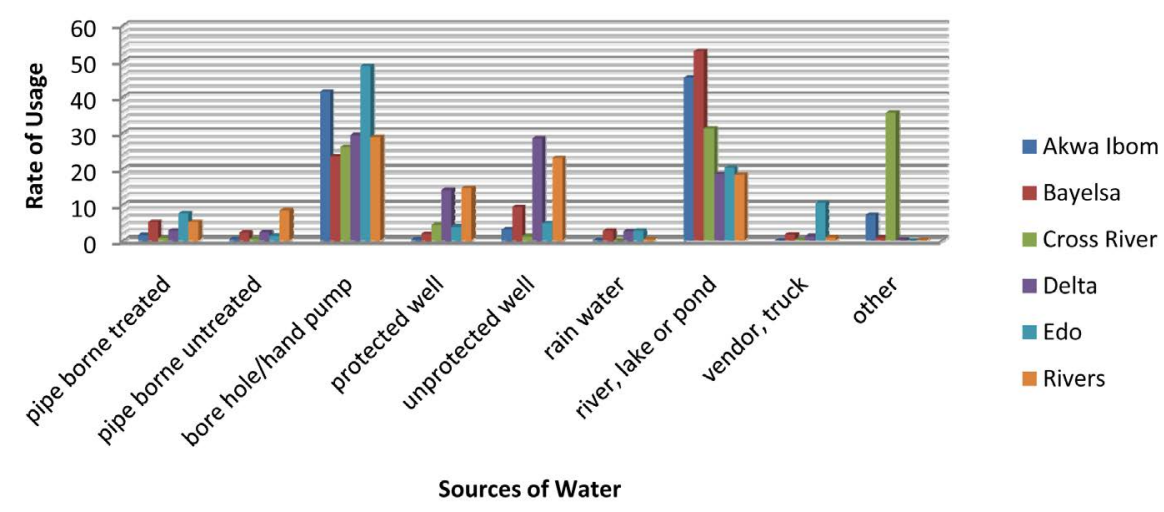

(f)

Figures 5. (a)-(f) Distribution of households by main source of water supply for each of the six geopolitical zones of Nigeria.

the politicians who control the State and Local Governments to embark on water management strategy that would benefit the people. They handle the programme whenever it exists with a great measure of unseriousness. Our investigation revealed that the politicians who are at the helm of water supply affairs both in the State, Local Government Areas and various departments are always faced with the dilemma of giving support to consumers on any unpopular water wise measures and that of leaving them to do otherwise. The appointment of unprofessional as commissioners for Public Utilities, a Ministry that oversees the activities of the Water Corporations in various States complicates the problem.

Most of these appointees usually assume their responsibilities with the intension of enriching themselves and any programme of the Water Corporation which is not in line with that aspiration is usually often ignored.

\subsection{Lack of Sustained Awareness Campaign}

The awareness level of WDM in various States Water Corporation is still low. To buttress this, the government's budgetary proposals have failed to provide the desired importance of this aspect of water management, conveying the impression that the concept is either not well understood or that its effects are not appreciated. It is important to understand that one of the outstanding ways by which WDM could succeed in any society is the ability of the people in that area to change their attitudes to water consumption. Based on this, any water authority or urban government that is unable to do this will not achieve much water conservation under WDM effort.

\subsection{Lack of Co-Ordination among Ministries}

For WDM option to achieve the desired success, it must be handled holistically. This is unfortunately what is lacking in the States where relevant ministries such as industry, commerce, education, environment, health and technology are not involved in taking the policy decision that would guide water consumers. Since water re- 
sources touch on a range of sectors, Ministries that are responsible for the above outlined areas should be involved in the discussion and assessment of issues that would lead to any water demand management policy. Many States Ministry of Public Utility or Water Resources which are supposed to serve as coordinating points have failed in this regard. The various States Water Corporation which are usually mere parastatals of either the Ministry of Public Utilities or Water Resources lack the capacity especially in terms of funding and authority to deal with other Ministries. The result of this is that the WDM lacks proper and closer supervision in most instances.

\subsection{Poor In-School Education}

In-school education as an instrument of WDM can be effective if well handled. Regrettably in some of our States only few schools undertake this responsibility. In many States, water education has not been made part of the school curriculum. Water Education should be given a good space within the social studies or civics scheme in our schools, with a view to developing attitudinal change on the children. When children are educated on water issues, families are invariably educated, as knowledge gained by these children would be carried back home and implemented.

\subsection{Lack of Monitoring Tools for WDM}

Many States Water Corporations lack modern monitoring tools to assist them in the monitoring of the WDM especially at the city level. For example, GIS/data base can be used advantageously to present data on flow rates and pressures to any district of any rural community or urban area. This could be used by network managers to detect potential leaks in parts of the city that are experiencing high pressures that could result in leaks and bursts. Furthermore, the Corporation does not have any type of database which could be used to further effects in quantifying leakages especially in terms of revenue.

\subsection{High Cost of Retrofitting Technologies}

The cost of retrofitting technologies are usually too high in the market and most times these high costs make them fall out of the reach of many residents. Added to this is the cost of labour in installing them. Our field investigation revealed that consumers are sceptical over retrofitting programmes as a result of these cost implications. This problems can be solved if the government can bear some of the material costs i.e. offer subsidy to enable people acquire them. Again, the programme should be made to start on a pilot scale, in the States.

WDM as a water management concept has been practised in some residential areas in our urban and rural communities. [11] explained the way it has been practiced in three low income districts of Enugu urban areas namely Ugbene in Abakpa Nike and Agricultural quarters in Asata mine road, Uwani and also in Nkpor district of Onitsha urban area. According to him, residents in these three urban areas organized themselves into Community Based Organizations (CBOs) to monitor compliance of consumers to WDM practices and noted that within a period of two years it was monitored, water demand decreased by $25 \%$ in affected districts of Enugu and 35\% in the affected district of Onitsha. However, Schouten and Moriarty (2006) were of the view that a key area affecting the management of community water supplies is the resource based itself. How reliable is it? Is quality sufficiently high and if not what can be done? Is there enough water for all domestic activities? Conversely, the issue of water demand is diametrically opposed to supply and their management techniques differ to the same extent. Even within the domain of demand, the residential water demand management seem to be at the root of the solution to the great dividing line between the quantity of water demand and supply. Whenever there is this great demand-supply gap, sanitation within the household suffers considerably. Based on this, we shall examine the water demand management in Nru Nsukka urban area, to show the effects of community approach to Water Demand Management.

The residents of Nru in Nsukka urban area have for long been battling with the best way to provide sufficient water supply and sanitation for its people. According to [12] the ward was able to attain only 22\% per capita water supply in 1997 of the Federal Government recommended minimum of 115 litres per capita per day (lcd). Again [13] noted that the 2009 per capita water demand level of the people was only 20.2 lcd, which was about 5 litres less than the situation in 1997. The reason for the above situation is the low level of urban water supply to the area by the Water Corporation. Faced with this problem, members of the community decided to take their 
destiny in their own hands by trying to develop and manage the available water quantities. Based on this, the community formed an organization in April 2009 which they called the Water Service Association and charged it with the responsibility of ensuring the provision of more water by households and managing same. The Association's first task was on how to improve supplies. On the basis of this thinking, they agreed to embark on rain water harvestation within the community based on the following methods:

1) Collection of rain water from all the zinc roofs of buildings in the community

2) Collection of run-off into shallow ponds or catch pits

3) Collection of rain water running down the stem of certain trees e.g. cocoanut tree.

In doing this, they ensured that all the houses located close together were connected to each other through water catchments made of zinc which are directed into a locally dug tank of high storage capacity. There are about 92 of such high storage tanks of 10,000 litres each.

Water collected in these catch pits and those from the stems of trees are used for less sanitary domestic activities. The entire water collection from zincs between April and October 2010 was estimated at 920,000 litres which gave 40 litres of water per person per day for 24,000 residents of the area which is enough to satisfy hygienic requirements of residents. The water demand management they adopted are outlined as follows:

1) Payment of fine for anybody who do not re use water for the activities where it could be done.

2) Imposition of fine on any consumer who embarks on lawn watering of any kind with water which is adjudged good for hygienic purposes including drinking and cooking.

3) Attracting the government to sensitize their people on the need to build low water or even nil water demand toilets. In this regard, ventilated improved (VIP) latrine has been popularised in the community. The advantage is that this type of toilet uses no water and at same time prevents flies and odour. In this way, the community achieved a low feasible technology option in sanitary requirements especially regarding human wastes.

4) Also the committee was able to develop a local tariff structure which accords with the conventional ones. In this regard, houses with modern water consuming facilities such as flush toilets, bath, shower system and wash hand basins are meant to be connected to the urban water supply to use the small quantities supplied to them by the water Corporation, but will pay $20 \%$ above the official government water tariff. This $20 \%$ which are normally termed as administrative charge are paid into the community's account and used to develop its water supply system.

5) The community raised a non interest loan from well-meaning members of the community to construct rain catchments and other water supply infrastructure.

6) Others who do not have water consuming facilities in their homes are meant to use water from the community water supply system and pay a flat rate of 100.00 per month.

7) The water service committee was also charged with the responsibility of local sanitation. Anyone who does not dump domestic refuse at the officially designated sites are fined. Again defecation in the bushes around peoples homes are forbidden, as offenders are sanctioned. With this, the committee ensures that the community water reservoirs and catch pits are relatively less polluted of faecal and physical matters.

8) Furthermore, the committee appeals to the residents to ensure that their water storage facilities at home are of minimal sanitary standard.

9) General water management discussions are carried out at the monthly town meetings. During this meeting, the committee members and sometimes the Water Corporation's officials are invited to talk on the best water wise uses at homes. This constant interaction with Corporation's officials help to expose every member of the community to water management practices.

The Nru Nsukka Water Demand Management operation serves as an eye opener to the ability of the local people to manage their water and sanitation. From available verifiable results, it was found that within just one year of its operation water demand in the community decreased by $10 \%$, by the second year it has reduced to $19 \%$ and the third year demand was down by $25 \%$. This, therefore, means that the community's average per capita water demand of over 140 litres per capita per day (lcd) came down to about 105 lcd just in 3 years. With more of the same efforts in sanitation, it was observed that there was an improved environmental quality as there was less pollution in water supply leading to about $20 \%$ reduction of the people afflicted by water borne diseases [14]. This result has indeed shown that it is not only the use of economic instruments that could achieve rational water demand reduction but other measures including sustained community effort. The emphasis on the centrality of water pricing mechanism as a water demand strategy as proposed by many authors including [15]-[17] 
focused primarily on the use of price to force down demand. The use of economic instruments for water demand management however, tends to work better in an area with a reliable and uninterrupted water supply as is the case in western cities. Many other studies have actually indicated that it is still difficult to ascertain if market based instruments applied to water demand management achieve the often lofty ambition of decreasing demand. The application of economic instrument in an environment without adequate water supply will surely not succeed as the consumers behaviour tend to ignore any price attached to a good which is not rightly supplied.

Also it has been found from the Nru-Nsukka studies, adequate sanitation could still be achieved in a water scarce environment by the adoption of improved toilet facilities and other less water demanding activities. Also it was observed that efforts at environmental education has the tendency of shifting the attitude of consumers from their original environmental mind-set to a new one in which the people now acquire positive attitudes to deal with the environment.

Community management of water supply is the only thing that can stem the widening water demand-supply gap being experienced by residents in both urban and rural communities in Nigeria. Communities should be allowed to initiate, develop and manage their water supply and sanitation. It is only under this condition that water and sanitation would be rationally managed to the extent that the aim of WDM could be achieved which is the water management that employs various measures to control waste and undue consumption. This can only succeed through community management of water and sanitation which in the South Eastern parts of Nigeria has a ready framework in place. This is because communities in the area are administered through town unions where members of the community are provided with the opportunity of asking questions and contributing to the improvement of any community project including water and sanitation projects. The Nru-Nsukka model has two advantages which are:

1) Government at various levels (Federal, State and Local Governments) should use this approach as a way of reducing government expenditure in community development.

2) Donors will look at it as an opportunity to focus and stretch development budgets towards effective implementation of water supply and sanitation facilities and to bypass the problem posed by corrupt and inefficient government officials [18].

The Nru-Nsukka example is one case of the adoption of the Demand Responsive Approach (DRA) to water and sanitation, a concept which is geared towards putting community management approaches into effect [19] [20].

\section{Conclusion}

Water Demand Management is a management concept that motivates consumers to regulate the amount and manner in which they access, use and dispose water to alleviate pressure on fresh water supplies. This approach is demand driven as against the old management method which is supply driven. As we have seen, Nigeria spends whooping sums of money to develop new sources from its rich water reserve but these are often misused by the application of poor management strategy. We have realised that a supply side approach in combination with weak and fragmented institutional structure as we have in Nigeria offer no real hope for improved water and sanitation. Community management approach is both demand driven and engages in often pragmatic demand management measures. This equips the community with home grown measures towards addressing the huge unmet water and sanitation needs of the people yawning for these services. Poor water resources management gives rise to poor sanitation and time to employ WDM to improve these services in Nigeria is long overdue.

\section{References}

[1] Bithas, K. and Stoforos, C. (2006) Estimating Urban Residential Water Demand Determinants and Forecasting Water Demand for Athens Metropolitan Area, 2000-2010. South Eastern Europe Journal of Economics, 1, 47-59.

[2] Ezenwaji, E.E. (2009) Municipal and Industrial Water Demand and Supply in Enugu Urban Area, Nigeria. Unpublished Ph.D. Thesis, University of Nigeria, Nsukka.

[3] Ezenwaji, E.E. (2012) Water Demand-Supply Gap in the Residential Sector of Enugu Urban Area and Implications for achieving the Millennium Development Goals (MDGs). The Colloquium on Thirty Years of Social Services in Nigeria, Benin, 25 $5^{\text {th }}$-28th March 2012.

[4] Kayaga, S. and Smout, I. (2007) Water Demand Management: A Key Building Block for Integrated Resource Planning for the City of the Future. Switch, 8, 30-35. 
[5] Renwick, M. and Archibald, S. (1998) Demand Side Management Policies for Residential Water Use: Who Bears the Conservation Burden? Land Economics, 74, 343-359. http://dx.doi.org/10.2307/3147117

[6] Ayoade, J.O. (1981) On Water Availability and Demand in Nigeria. Water Supply and Management, 5, 361-372.

[7] Ayoade, J.O. (1975) Water Resources and Their Development in Nigeria. Hydrological Science Bulletin, 20, 581-591. http://dx.doi.org/10.1080/02626667509491589

[8] Irokalibe, I.J. (2008) Water Management in Federal and Federal Type Countries: Nigerian Perspective. Forum of Federations, Zaria, 2, 49-60.

[9] Cech, T.V. (2005) Principles of Water Resources: History Development Management and Policy. John Wiley and Sons, New Jersey.

[10] Ezemonye, M.N. (2007) Strategies for Water Demand Management: State of the Art. Doctoral Research Seminar II, Department of Geography, University of Nigeria, Nsukka.

[11] Ezenwaji, E.E. (2003) Urgent Water Demand Management in Nigeria. Proceedings of the 29th WEDC International Conference, Abuja, 22-26 September 2003.

[12] Obeta, M.C. (1997) Spatial Patterns of Residential Water Demand and Supply in Nsukka Urban Area of Enugu State, Nigeria. Unpublished Master's Thesis, University of Nigeria, Nsukka.

[13] Anyaorah, B.O. (2010) Water Demand in Selected Wards of Nsukka Urban Area, Nigeria. Urban Water Affairs, 16, 114-122.

[14] Ugwoke, S.N. (2011) Personal Communication.

[15] Espey, M.J. and Shaw, W.D. (1997) Price Elasticity of Residential Demand for Water: A Meta Analysis. Water Resources Research, 33, 1369-1374. http://dx.doi.org/10.1029/97WR00571

[16] Renzetti, S. (2005) Economic Instruments and Canadian Industrial Water Use. Canadian Water Resources Journal, 30, 21-30. http://dx.doi.org/10.4296/cwrj300121

[17] Cantin, B., Shrubsole, D. and Ait-Ouyahia, M. (2005) Using Economic Instruments for Water Demand Management: Introduction. Canadian Water Resources Journal, 30, 1-10. http://dx.doi.org/10.4296/cwrj30011

[18] Schouten, T. and Moriarty, P. (2006) Community Water, Management from Systems to Services in Rural Areas. ITDG Publishing, London.

[19] Sara, J. and Katz, T. (1997) Making Rural Water Supply Sustainable. Report on the Impact of Project Rules, UNDPWord Bank Water \& Sanitation Programme, Washington DC.

[20] World Bank (2002) Rural Water Supply and Sanitation Lacks the Information on Demand Responsiveness (DRA). World Bank Report, Washington DC. 